630.7
$I \ell \quad 6 b$
no .648
cop. 8





\section{UNIVERSITY OF ILLINOIS LIBRARY AT URBANA-CHAMIPAIGN

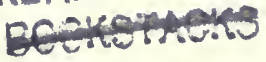



630.7

Ile6 6

no. 648

cop. 8

\section{Relation of}

\section{WHEAT ACREAGE AND PRODUCTION}

To Wheat, Corn, Oat, and Soybean Prices

\section{In Illinois}

By C. P. Schumaier

\section{SEP 261990}

Bulletin 648

University of Illinois - Agricultural Experiment Station 


\section{CONTENTS}

Scope of the Study and Method of Analysis.......... 3

Illinois Wheat Production and Acreage.............4

Price and Revenue Ratios Between Wheat and

Competing Crops ...................

Relation of Wheat Production and Acreage to

Price and Revenue Ratios................1

Illinois Wheat Production and Acreage, by Districts....... II

Summary........................

Conclusions........................... 19 


\title{
Relation of Wheat Acreage and Production to Wheat, Corn, Oat, and Soybean Prices in Illinois
}

\author{
By C. P. Schumaier, Assistant Professor of Agricultural Economics
}

$\mathrm{T}$

HE AGRICULTURAL RESOURCES of Illinois can be devoted to a variety of uses because of the state's rich soil, long growing season, and abundant, reliable rainfall. Illinois farmers may vary their cropproduction patterns considerably among wheat, other small grains, corn and sorghum, and oilseed crops in response to economic incentives. Farmers in Illinois may operate on the economic principle of comparative advantage. Few groups of farmers are so fortunate. Farmers on the cold and dry margins must grow crops with the least disadvantage compared with richer agricultural regions.

Although Illinois farmers as a whole are fortunately endowed, the most productive land and the most favorable climatic conditions are in central and east-central Illinois. Southern Illinois land is much less fertile, yields are more variable, and alternatives more restricted than in central Illinois. Also, the state is some 400 miles long from north to south. Spring oats, for example, do well only from the central part of the state north, and winter oats are a dependable crop only in the extreme southern part of the state.

Because of the nature of agricultural resources in Illinois, experience in the state should provide a good test of two hypotheses with respect to wheat production: (1) wheat acreage and production decline in Illinois when prices are unfavorable and increase when prices are favorable compared with prices of competing crops, and (2) wheatproduction adjustments related to price are greater in central Illinois, where there are more good alternatives, than in southern Illinois, where alternatives are more restricted.

\section{Scope of the Study and Method of Analysis}

This report analyzes production and acreage of wheat in Illinois in relation to the price-per-bushel and revenue-per-acre ratios between wheat and corn, oats, and soybeans during the years 1927-1958. As used in this study, the term "wheat" refers to winter wheat. A small amount of spring wheat was produced in the early years but the amount is now so negligible that spring wheat is no longer reported separately.

Consideration of revenue-per-acre ratios is particularly important 
for this study because of the changes in yields due to technological advances during the period studied. For example, if during a given period of time corn had the same price-per-bushel ratios but increasing average yields relative to competing wheat, oats, and soybeans, then corn would earn more revenue per acre than the other crops and become relatively more profitable.

Data for this study were taken from reports of the Illinois Cooperative Crop Reporting Service for the years 1927 through 1958 and from annual issues of Agricultural Statistics, published by the U.S. Department of Agriculture, 1929 through 1958. Percentages and averages were the only measures used to test the hypotheses.

Three periods were selected for comparison: 1929-1938, 19421947, and 1952-1957. They represent, respectively, the prewar average, the situation during and immediately following World War II, and the postwar average. The periods are referred to in the text as prewar, war, and postwar, to make the reading easier.

\section{Illinois Wheat Production and Acreage}

Production. During the prewar period (1929-1938) Illinois produced an average of 36 million bushels of wheat annually (Table 1). The record year during this period was 1931 with 48.9 million bushels.

Production began to fall in 1938 and was down to 12.8 million bushels in 1942. Production during the war period (1942-1947) averaged only 21 million bushels annually, 42 percent less than the prewar average.

In 1947 production began to increase rapidly and reached a record high of almost 61 million bushels in 1956. Average annual production during the postwar period (1952-1957) was almost 50 million bushels, more than double the production during the war period and 38 percent more than the average of the prewar period.

Illinois ranked ninth among states in total wheat production in the 1947-1956 decade. In the 1941-1950 decade, Illinois had ranked thirteenth.

Illinois' percentage share of total United States wheat production ranged from 3.4 to 6.9 and averaged 4.8 percent in the prewar period (Table 1). The decline in Illinois wheat production after 1937 was accompanied by a decline in the state's percentage share of total U.S. production; in 1942 Illinois' percentage share fell to less than one-third of the prewar average. Illinois produced between 1.3 and 2.3 percent and an average of 2.0 percent of U.S. wheat during the six-year war period. 
Beginning in 1948 the uptrend in Illinois wheat production raised Illinois' percentage share of total production to a postwar high of 6.1 percent in 1956. For the six-year postwar period, Illinois produced 4.7 percent of the nation's wheat, a slightly smaller share than the 4.8 percent of the prewar period, although total Illinois production averaged 38 percent more than in the prewar period.

Table 1. - Illinois and United States Wheat Production and Illinois Production as a Percent of Total United States Production, 1927-1958

\begin{tabular}{|c|c|c|c|}
\hline Year & Illinois & $\begin{array}{l}\text { United } \\
\text { States }\end{array}$ & $\begin{array}{l}\text { Relation of } \\
\text { Illinois produc- } \\
\text { tion to U. S. } \\
\text { production }\end{array}$ \\
\hline & \multicolumn{2}{|c|}{ million bushels } & percent \\
\hline 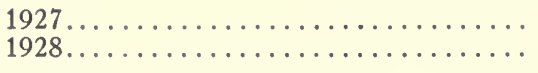 & $\begin{array}{l}31.0 \\
19.5\end{array}$ & $\begin{array}{l}875.1 \\
914.4\end{array}$ & $\begin{array}{l}3.5 \\
2.1\end{array}$ \\
\hline 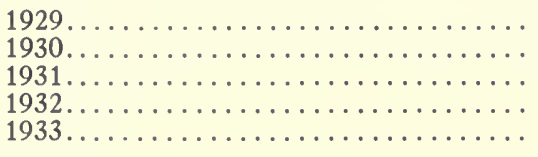 & $\begin{array}{l}30.8 \\
36.9 \\
48.9 \\
26.0 \\
30.7\end{array}$ & $\begin{array}{l}824.2 \\
886.5 \\
941.5 \\
756.3 \\
552.2\end{array}$ & $\begin{array}{l}3.7 \\
4.2 \\
5.2 \\
3.4 \\
5.6\end{array}$ \\
\hline 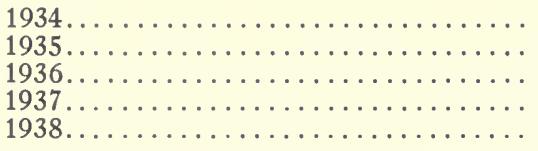 & $\begin{array}{l}36.5 \\
30.1 \\
36.4 \\
44.9 \\
40.9\end{array}$ & $\begin{array}{l}526.1 \\
628.2 \\
629.9 \\
873.9 \\
919.9\end{array}$ & $\begin{array}{l}6.9 \\
4.8 \\
5.8 \\
5.1 \\
4.4\end{array}$ \\
\hline 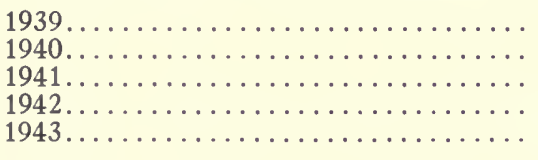 & $\begin{array}{l}39.8 \\
39.3 \\
34.3 \\
12.8 \\
17.0\end{array}$ & $\begin{array}{l}741.2 \\
814.6 \\
942.0 \\
969.4 \\
843.8\end{array}$ & $\begin{array}{l}5.4 \\
4.8 \\
3.6 \\
1.3 \\
2.0\end{array}$ \\
\hline 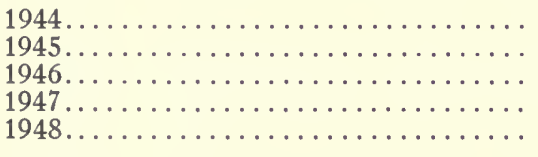 & $\begin{array}{l}24.3 \\
24.8 \\
19.4 \\
28.3 \\
38.5\end{array}$ & $\begin{array}{l}1,060.1 \\
1,107.6 \\
1,152.1 \\
1,358.9 \\
1,294.9\end{array}$ & $\begin{array}{l}2.3 \\
2.2 \\
1.7 \\
2.1 \\
3.0\end{array}$ \\
\hline 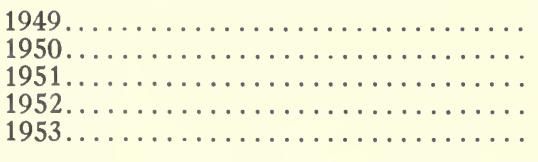 & $\begin{array}{l}44.0 \\
27.6 \\
33.4 \\
42.4 \\
59.4\end{array}$ & $\begin{array}{r}1,098.4 \\
1,019.4 \\
988.2 \\
1,306.4 \\
1,173.1\end{array}$ & $\begin{array}{l}4.0 \\
2.5 \\
3.4 \\
3.2 \\
5.1\end{array}$ \\
\hline 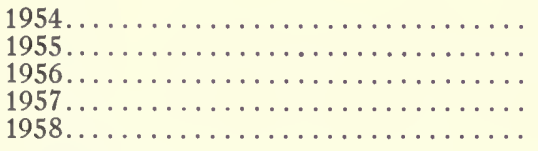 & $\begin{array}{l}47.8 \\
52.0 \\
60.9 \\
36.5 \\
54.2\end{array}$ & $\begin{array}{r}983.9 \\
934.7 \\
1,004.3 \\
950.7 \\
1,462.2\end{array}$ & $\begin{array}{l}4.9 \\
5.6 \\
6.1 \\
3.8 \\
3.7\end{array}$ \\
\hline $\begin{array}{l}\text { Average } \\
\quad 1929-1938 \text { (prewar) } \ldots \ldots \ldots \ldots \ldots \ldots \ldots \ldots \\
1942-1947 \text { (war) } \ldots \ldots \ldots \ldots \ldots \ldots \ldots \\
1952-1957 \text { (postwar) } \ldots \ldots \ldots \ldots \ldots\end{array}$ & $\begin{array}{l}36.2 \\
21.1 \\
49.8\end{array}$ & $\begin{array}{r}753.9 \\
1,082.0 \\
1,058.9\end{array}$ & $\begin{array}{l}4.8 \\
2.0 \\
4.7\end{array}$ \\
\hline
\end{tabular}




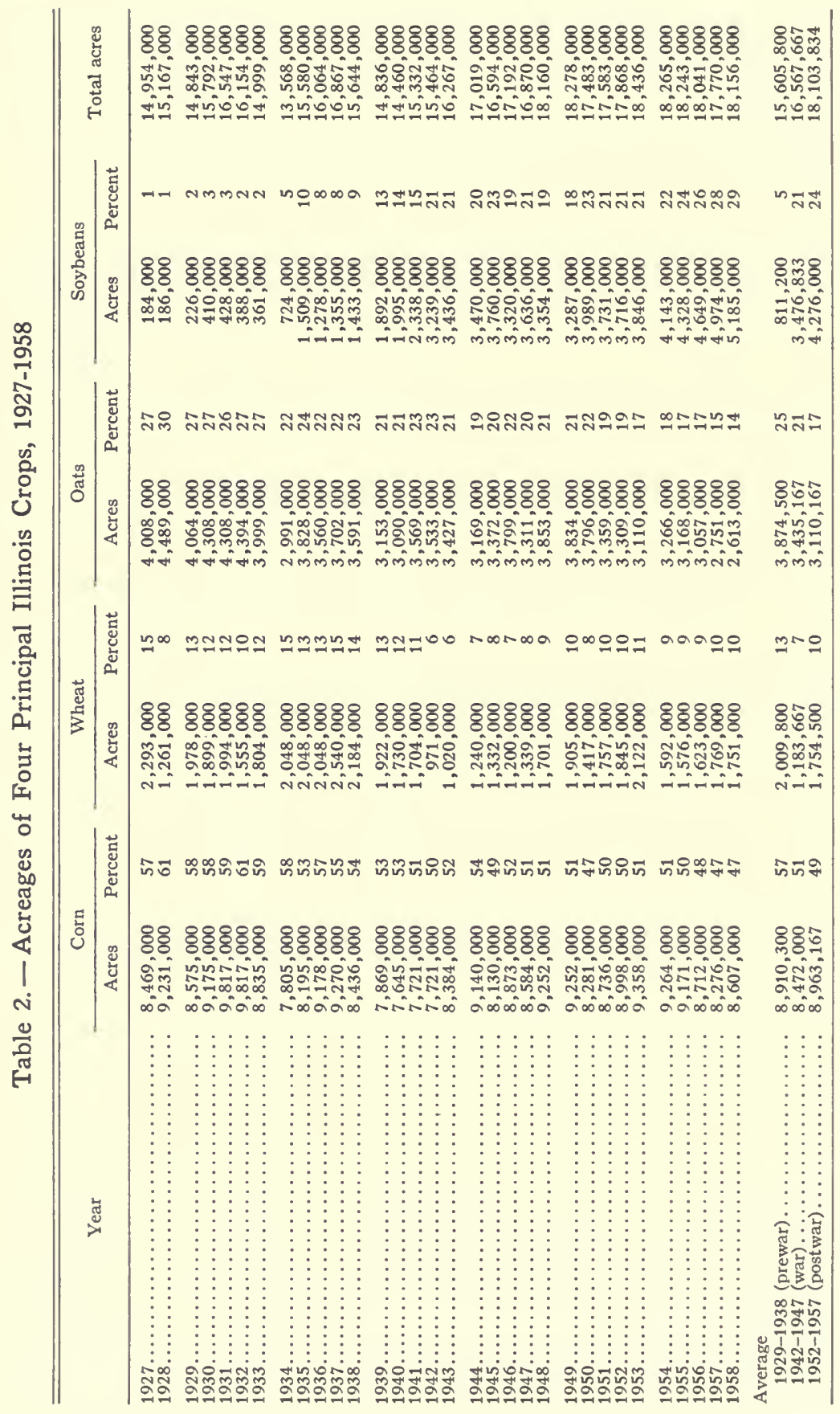


Acreage. The total annual acreage in the four principal Illinois grain crops increased from about 15 million to 18 million acres from 1927 to 1958 (Table 2). Wheat acreage declined from about 2 million acres in the prewar period to about 1.2 million during the war period and then increased again to 1.8 million in the postwar period. The acreage in soybeans increased from less than 200,000 in 1927 to over 5 million in 1958, while oat acreage declined from 4 million to less than 3 million. Corn acreage showed no consistent trend, ranging from a low of 7.6 million to a high of 9.8 million during the 32 -year period.

Corn occupied 50 percent or more of the land in the four crops from 1927 to 1955 except for two years (Table 2). Since 1955 corn acreage has been just under half of the total acreage. The percentage of acres in oats declined steadily from 27 percent in 1927 to only 14 percent in 1958, while the percentage in soybeans increased steadily from 1 percent in 1927 to 29 percent in 1958. The percentage of acres in wheat averaged 13 percent in the prewar period, decreased to 7 percent during the war period, and rose during the postwar period to 10 percent.

\section{Price and Revenue Ratios Between Wheat and Competing Crops}

Price-per-bushel ratios. Over the 31-year period 1927-1957 the price of wheat in Illinois averaged 140.58 percent of the price of corn, 268.81 percent of the price of oats, and 85.84 percent of the price of soybeans (Tables 3 and 4). Expressed in another way, one bushel of wheat was worth 1.41 bushels of corn, 2.69 bushels of oats, and 0.86 bushel of soybeans.

One bushel of wheat was worth 1.46 bushels of corn in the prewar period, 1.29 bushels of corn in the war period, and 1.44 bushels of corn in the postwar period. In effect wheat prices relative to corn prices decreased 12 percent from prewar to war and increased 11 percent from war to postwar.

Relative to oat prices, wheat prices decreased 19 percent from prewar to war and increased 25 percent from war to postwar. One bushel of wheat was worth 2.78 bushels of oats prewar, 2.25 bushels war, and 2.98 bushels postwar.

In the postwar period price relationships between wheat and corn and oats were similar to those of the prewar period. Soybeans, how- 


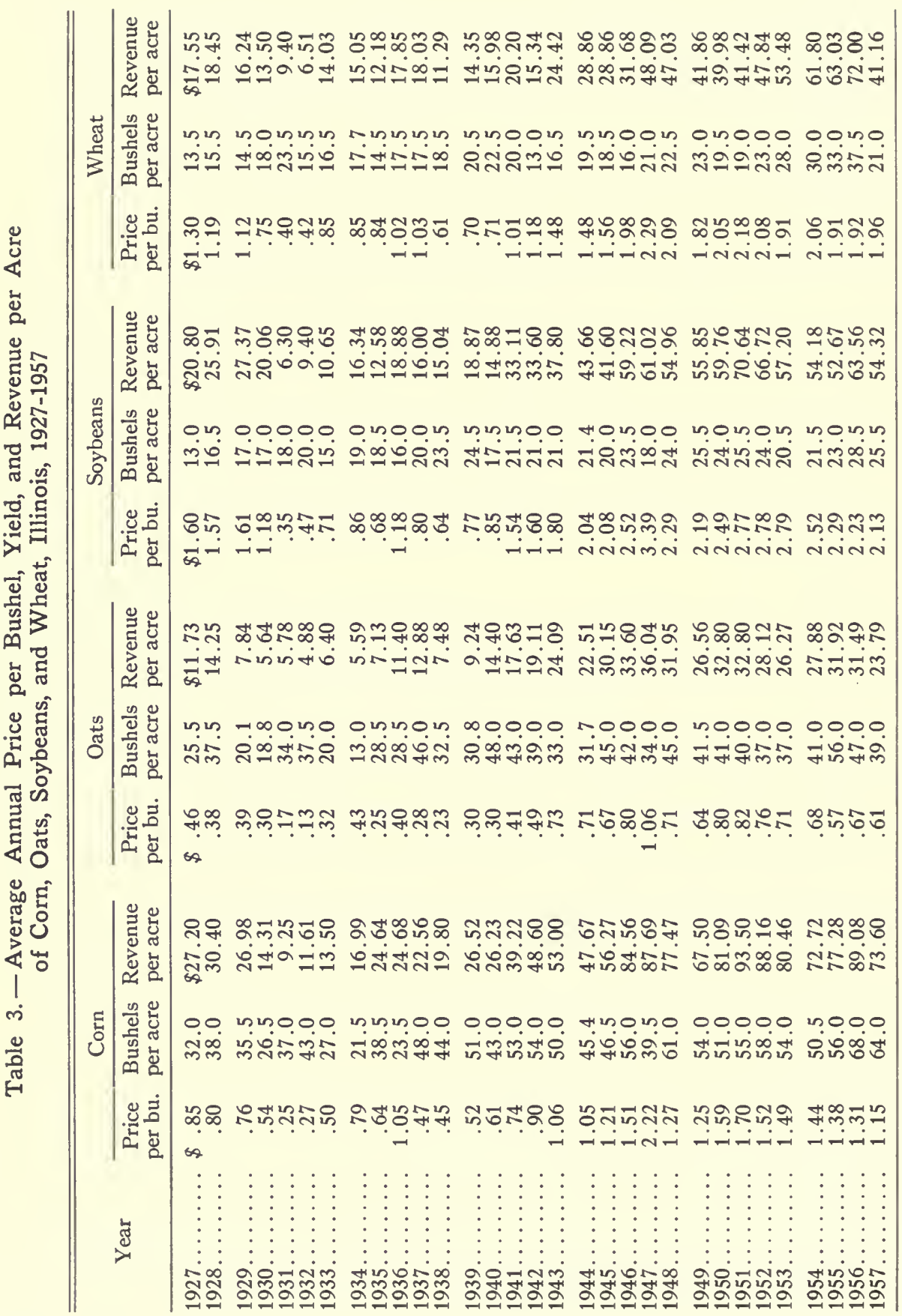


ever, show a significant price advantage over wheat in the postwar compared to the prewar period. One bushel of wheat was worth 0.99 bushel of soybeans prewar but only 0.81 bushel postwar; during the war one bushel of wheat was worth 0.75 bushel of soybeans. Wheat

Table 4. - Wheat Price per Bushel and Revenue per Acre as Percents of Corn, Oat, and Soybean Price per Bushel and Revenue per Acre, Illinois, 1927-1957

\begin{tabular}{|c|c|c|c|c|c|c|}
\hline \multirow{2}{*}{ Year } & \multicolumn{6}{|c|}{$\begin{array}{l}\text { Relation of wheat price and revenue to price and revenue of: } \\
\begin{array}{ccc}\text { Corn } & \text { Oats } & \text { Soybeans }\end{array}\end{array}$} \\
\hline & $\begin{array}{l}\text { Price } \\
\text { per bu. }\end{array}$ & $\begin{array}{l}\text { Revenue } \\
\text { per acre }\end{array}$ & $\begin{array}{l}\text { Price } \\
\text { per bu. }\end{array}$ & $\begin{array}{l}\text { Revenue } \\
\text { per acre }\end{array}$ & $\begin{array}{l}\text { Price } \\
\text { per bu. }\end{array}$ & $\begin{array}{l}\text { Revenue } \\
\text { per acre }\end{array}$ \\
\hline & \multicolumn{6}{|c|}{ percent } \\
\hline $\begin{array}{l}1927 \ldots \ldots \ldots \ldots \ldots \\
1928 \ldots \ldots \ldots \ldots\end{array}$ & $\begin{array}{l}153 \\
149\end{array}$ & $\begin{array}{l}65 \\
61\end{array}$ & 283 & $\begin{array}{l}150 \\
129\end{array}$ & $\begin{array}{l}81 \\
76\end{array}$ & $\begin{array}{l}84 \\
71\end{array}$ \\
\hline $\begin{array}{l}1929 \ldots \ldots \ldots \ldots \\
1930 \ldots \ldots \ldots \ldots \ldots \\
1931 \ldots \ldots \ldots \ldots \ldots \\
1932 \ldots \ldots \ldots \ldots \\
1933 \ldots \ldots \ldots \ldots\end{array}$ & $\begin{array}{l}147 \\
139 \\
160 \\
156 \\
170\end{array}$ & $\begin{array}{r}60 \\
94 \\
102 \\
56 \\
104\end{array}$ & $\begin{array}{l}287 \\
250 \\
235 \\
323 \\
266\end{array}$ & $\begin{array}{l}207 \\
239 \\
163 \\
133 \\
219\end{array}$ & $\begin{array}{r}70 \\
64 \\
114 \\
89 \\
120\end{array}$ & $\begin{array}{r}59 \\
67 \\
149 \\
69 \\
132\end{array}$ \\
\hline $\begin{array}{l}1934 \ldots \ldots \ldots \ldots \\
1935 \ldots \ldots \ldots \ldots \ldots \\
1936 \ldots \ldots \ldots \ldots \ldots \\
1937 \ldots \ldots \ldots \ldots \\
1938 \ldots \ldots \ldots \ldots\end{array}$ & 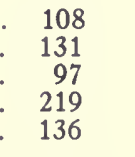 & $\begin{array}{l}89 \\
49 \\
72 \\
80 \\
57\end{array}$ & $\begin{array}{l}198 \\
336 \\
255 \\
368 \\
265\end{array}$ & $\begin{array}{l}269 \\
171 \\
157 \\
140 \\
151\end{array}$ & $\begin{array}{r}99 \\
124 \\
86 \\
129 \\
95\end{array}$ & $\begin{array}{r}92 \\
97 \\
95 \\
113 \\
75\end{array}$ \\
\hline $\begin{array}{l}1939 \ldots \ldots \ldots \ldots \\
1940 \ldots \ldots \ldots \ldots \ldots \\
1941 \ldots \ldots \ldots \ldots \ldots \\
1942 \ldots \ldots \ldots \ldots \ldots \\
1943 \ldots \ldots \ldots \ldots\end{array}$ & $\begin{array}{l}135 \\
116 \\
136 \\
131 \\
140\end{array}$ & $\begin{array}{l}54 \\
61 \\
52 \\
32 \\
46\end{array}$ & $\begin{array}{l}233 \\
237 \\
246 \\
241 \\
203\end{array}$ & $\begin{array}{r}155 \\
111 \\
115 \\
80 \\
101\end{array}$ & $\begin{array}{l}91 \\
84 \\
66 \\
74 \\
82\end{array}$ & $\begin{array}{r}76 \\
107 \\
61 \\
46 \\
65\end{array}$ \\
\hline $\begin{array}{l}1944 \ldots \ldots \ldots \ldots \\
1945 \ldots \ldots \ldots \ldots \ldots \\
1946 \ldots \ldots \ldots \ldots \\
1947 \ldots \ldots \ldots \ldots \\
1948 \ldots \ldots \ldots \ldots\end{array}$ & $\begin{array}{l}141 \\
129 \\
131 \\
103 \\
165\end{array}$ & $\begin{array}{l}61 \\
51 \\
37 \\
55 \\
61\end{array}$ & $\begin{array}{l}208 \\
233 \\
248 \\
216 \\
294\end{array}$ & $\begin{array}{r}128 \\
96 \\
94 \\
133 \\
147\end{array}$ & $\begin{array}{l}73 \\
75 \\
79 \\
68 \\
91\end{array}$ & $\begin{array}{l}66 \\
69 \\
53 \\
79 \\
86\end{array}$ \\
\hline $\begin{array}{l}1949 \ldots \ldots \ldots \ldots \\
1950 \ldots \ldots \ldots \ldots \\
1951 \ldots \ldots \ldots \ldots \\
1952 \ldots \ldots \ldots \ldots \\
1953 \ldots \ldots \ldots \ldots\end{array}$ & $\begin{array}{l}146 \\
. \quad 129 \\
\\
128 \\
137 \\
128\end{array}$ & $\begin{array}{l}62 \\
49 \\
44 \\
54 \\
66\end{array}$ & $\begin{array}{l}284 \\
256 \\
266 \\
274 \\
269\end{array}$ & $\begin{array}{l}158 \\
122 \\
126 \\
170 \\
204\end{array}$ & $\begin{array}{l}83 \\
82 \\
79 \\
75 \\
68\end{array}$ & $\begin{array}{l}75 \\
67 \\
59 \\
72 \\
93\end{array}$ \\
\hline $\begin{array}{l}1954 \ldots \ldots \ldots \ldots \\
1955 \ldots \ldots \ldots \ldots \ldots \\
1956 \ldots \ldots \ldots \ldots \\
1957 \ldots \ldots \ldots \ldots\end{array}$ & $\begin{array}{r}143 \\
\cdot \quad 138 \\
\cdot \quad 147 \\
. \quad 170\end{array}$ & $\begin{array}{l}85 \\
82 \\
81 \\
56\end{array}$ & $\begin{array}{l}303 \\
335 \\
287 \\
321\end{array}$ & $\begin{array}{l}222 \\
197 \\
229 \\
173\end{array}$ & $\begin{array}{l}82 \\
83 \\
86 \\
92\end{array}$ & $\begin{array}{r}114 \\
120 \\
113 \\
76\end{array}$ \\
\hline $\begin{array}{l}\text { Average } \\
1927-1957 \ldots \ldots \\
1929-1938 \ldots \ldots \\
1942-1947 \ldots \ldots \\
1952-1957 \ldots \ldots\end{array}$ & $\begin{array}{r} \\
. \quad 140.58 \\
. \quad 146.30 \\
129.17 \\
\quad 143.83\end{array}$ & $\begin{array}{l}63.81 \\
76.30 \\
47.00 \\
70.67\end{array}$ & $\begin{array}{l}268.81 \\
278.30 \\
224.83 \\
298.17\end{array}$ & $\begin{array}{l}157.71 \\
184.90 \\
105.33 \\
199.17\end{array}$ & $\begin{array}{l}85.84 \\
99.00 \\
75.17 \\
81.00\end{array}$ & $\begin{array}{l}83.87 \\
94.80 \\
63.00 \\
98.00\end{array}$ \\
\hline
\end{tabular}


prices relative to soybean prices decreased 24 percent from prewar to war and increased only 7 percent from war to postwar.

Revenue-per-acre ratios. Revenue per acre is dependent upon both price and yield. Hybrid corn was introduced in the 1930's and yields have increased rapidly since then (Table 3 ). From the prewar to the war period average yields of corn increased 41 percent, while oat yields increased 34 percent and soybean yields, 13 percent. Wheat yields were practically the same in both periods.

Wheat yields increased rapidly after World War II. From the war to the postwar period wheat yields increased 66 percent, almost as much as the 70-percent gain that corn yields showed from the prewar to the postwar period. Oat and soybean yields increased from war to postwar, but at a slower rate than corn and wheat.

Wheat revenue per acre averaged about three-fourths (76.30 percent) that of corn in the prewar period and slightly less than threefourths (70.67 percent) in the postwar period (Table 4). During the war period wheat returned less than half ( 47 percent) as much revenue per acre as corn.

Oat prices were particularly favorable during the war period and yields increased relative to wheat. As a result, wheat revenue per acre, which had been almost double (184.90 percent) that of oats in the prewar period, fell below oat revenue in three of the six war years (Table 3 ). For the six-year war period, wheat averaged only a little more revenue per acre (105.33 percent) than oats. In the postwar period wheat revenue per acre was double (199.17 percent) that of oats.

Wheat revenue per acre averaged just a little less than that of soybeans in both the prewar ( 94.80 percent) and postwar (98 percent) periods. However, during the war period wheat averaged only 63 percent as much revenue per acre as soybeans.

These price and revenue relationships show that wheat was at a considerable disadvantage compared with corn, oats, and soybeans during the war period. There are two reasons: (1) wheat prices increased less than the other crop prices during the war period, and (2) wheat yields increased less from the prewar through the war period than those of the other grains.

In the postwar period price relationships returned to more nearly the prewar pattern and wheat yields increased rapidly. This reversal of the war-period price and yield trends resulted in wheat revenue per acre in the postwar period that was higher in relation to oats and soybeans than in the prewar period. The postwar wheat revenue per acre was almost as high in relation to corn as in the prewar period. 


\section{Relation of Wheat Production and Acreage to Price and Revenue Ratios}

Wheat acreage and production clearly show an association with wheat's unfavorable revenue-per-acre relationships to other crops during the war period and with the improvement (with respect to wheat) in revenue ratios in the postwar period.

From the prewar to the war period, the revenue-per-acre ratio of wheat to corn decreased 38 percent, that of wheat to oats decreased 43 percent, and that of wheat to soybeans decreased 33 percent. In the same period, wheat production decreased 42 percent and acreage decreased 41 percent.

From the war to the postwar period the revenue-per-acre ratios increased in favor of wheat by 50 percent relative to corn, by 89 percent relative to oats, and by 56 percent relative to soybeans. Wheat production from war to postwar increased by 136 percent and acreage increased by 48 percent.

Thus the necessary conditions to establish the validity of the first hypothesis are met. The decline in war-period wheat acreage and production was associated with declining price and revenue ratios for wheat compared with competing crops. The return to approximately prewar price and revenue relationships in the postwar period was associated with greatly increased wheat acreage and production.

\section{Illinois Wheat Production and Acreage, by Districts}

Production and acreage distribution. Tables 5 and 6 show the distribution of wheat acreage and production among crop-reporting districts in Illinois (Fig. 1). Three districts appear to have long-time trends. The northwest and central districts have a downward trend in their percentage shares of total wheat acreage and production. The east southeast district has an upward trend.

During the war period (1942-1947), when total wheat acreage in the state declined from the prewar average, the west, central, east, and west southwest percentage shares of total acreage and production declined, while the east southeast, southwest, and southeast percentage shares increased. The northwest and northeast shares are negligible and showed little change.

From the war to the postwar (1952-1957) period, the west and east increased their percentage shares of total wheat acreage and production, while the southwest and southeast shares declined. The warperiod decline in the central area appears to have stopped, although no 


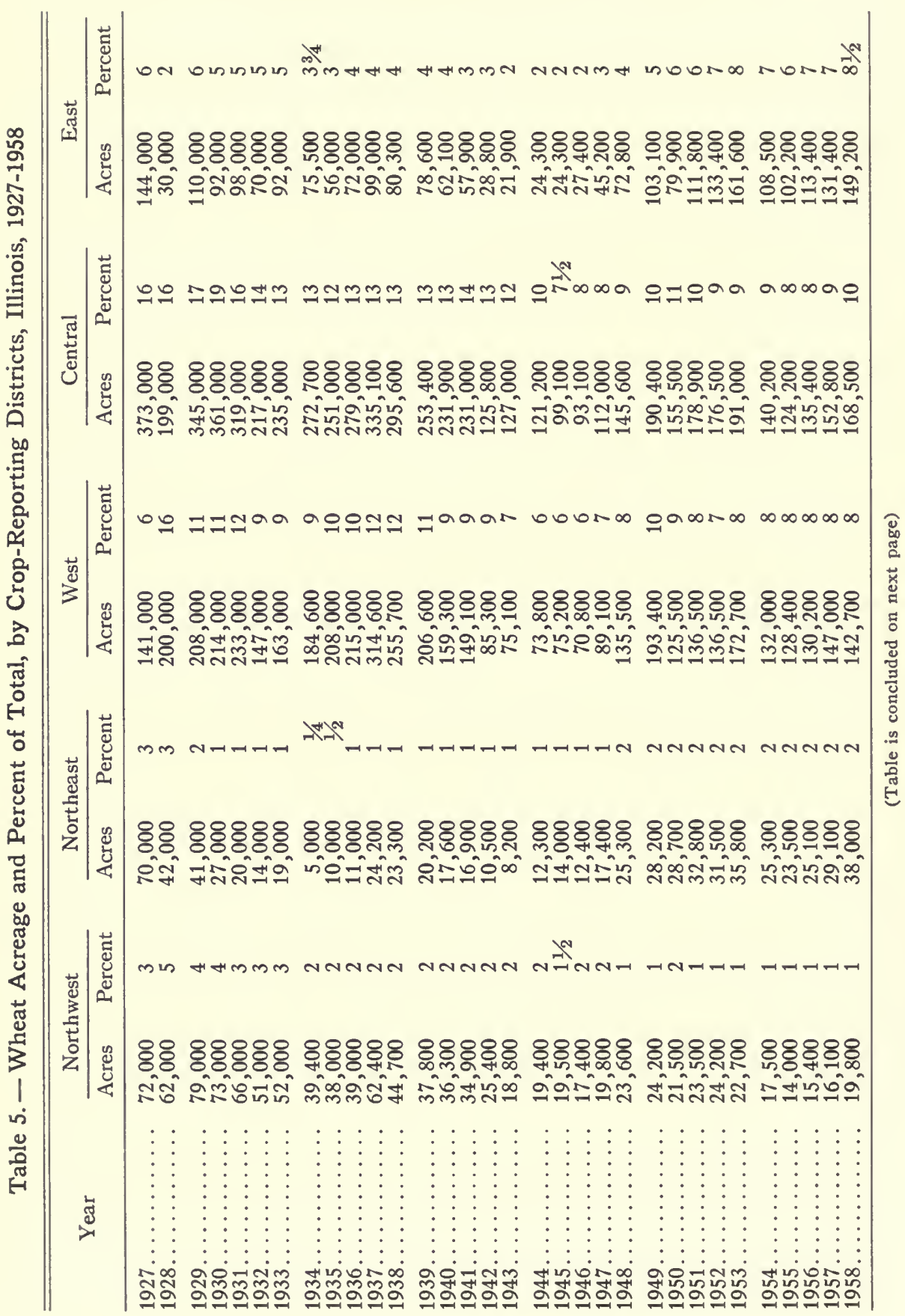




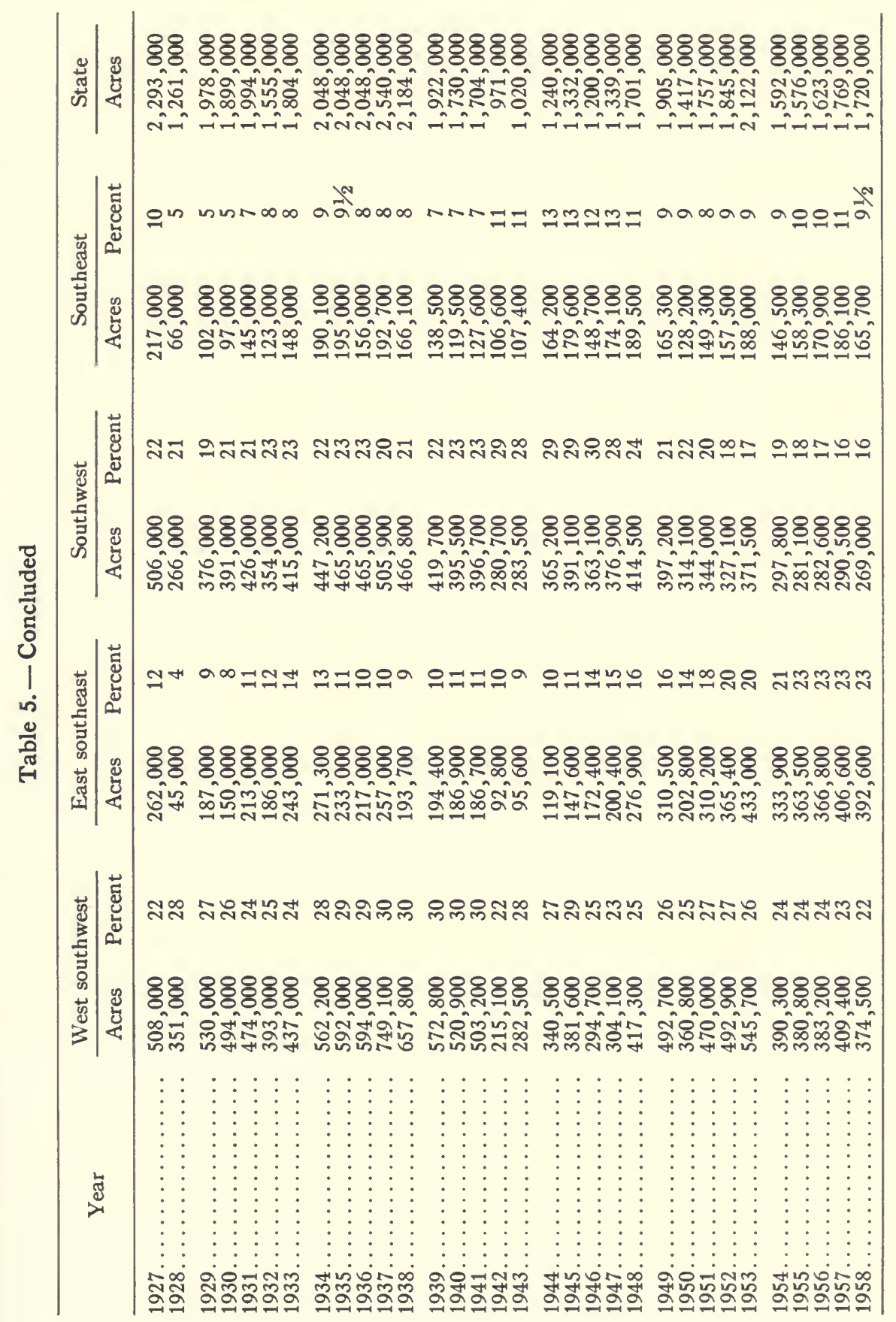




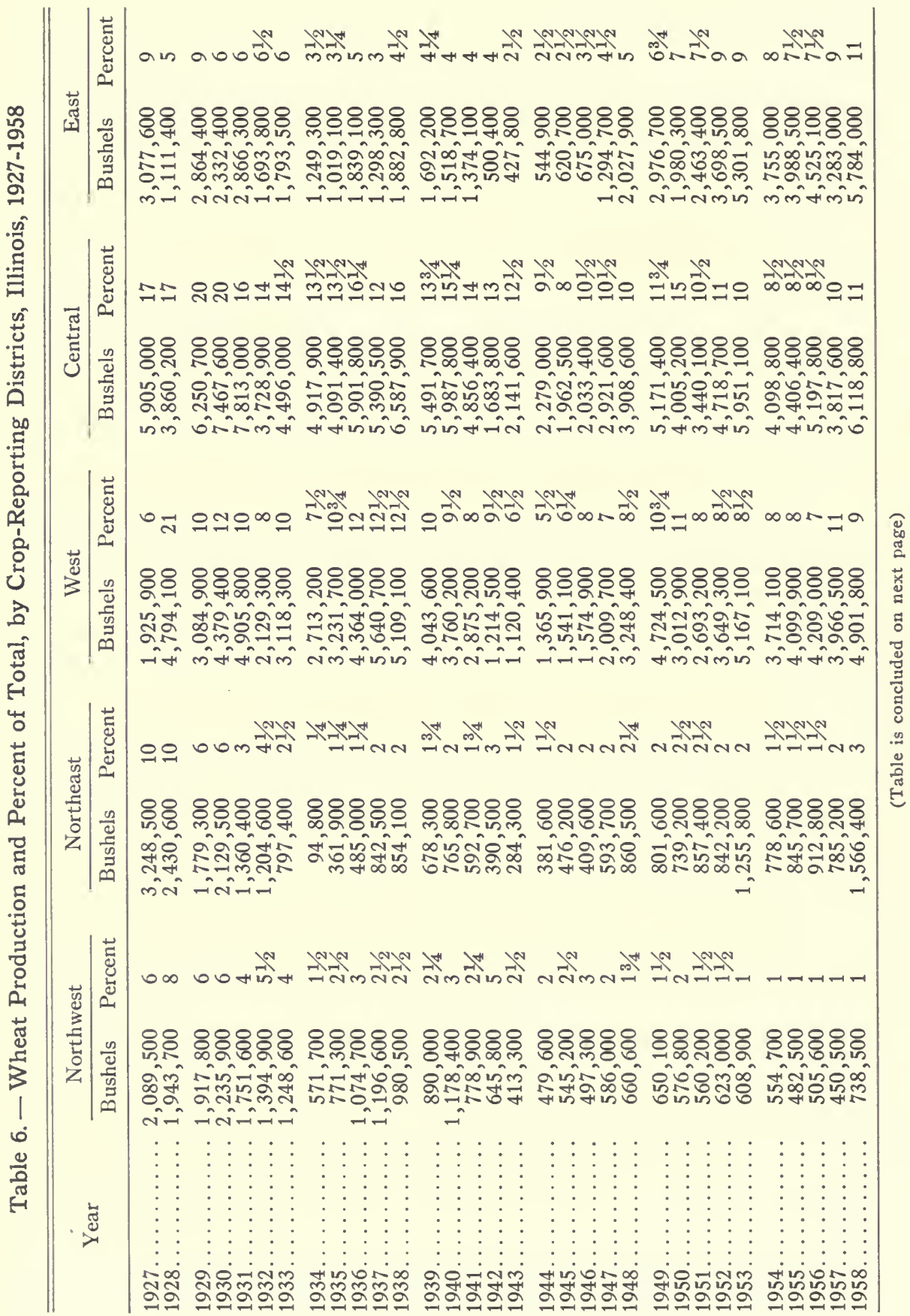




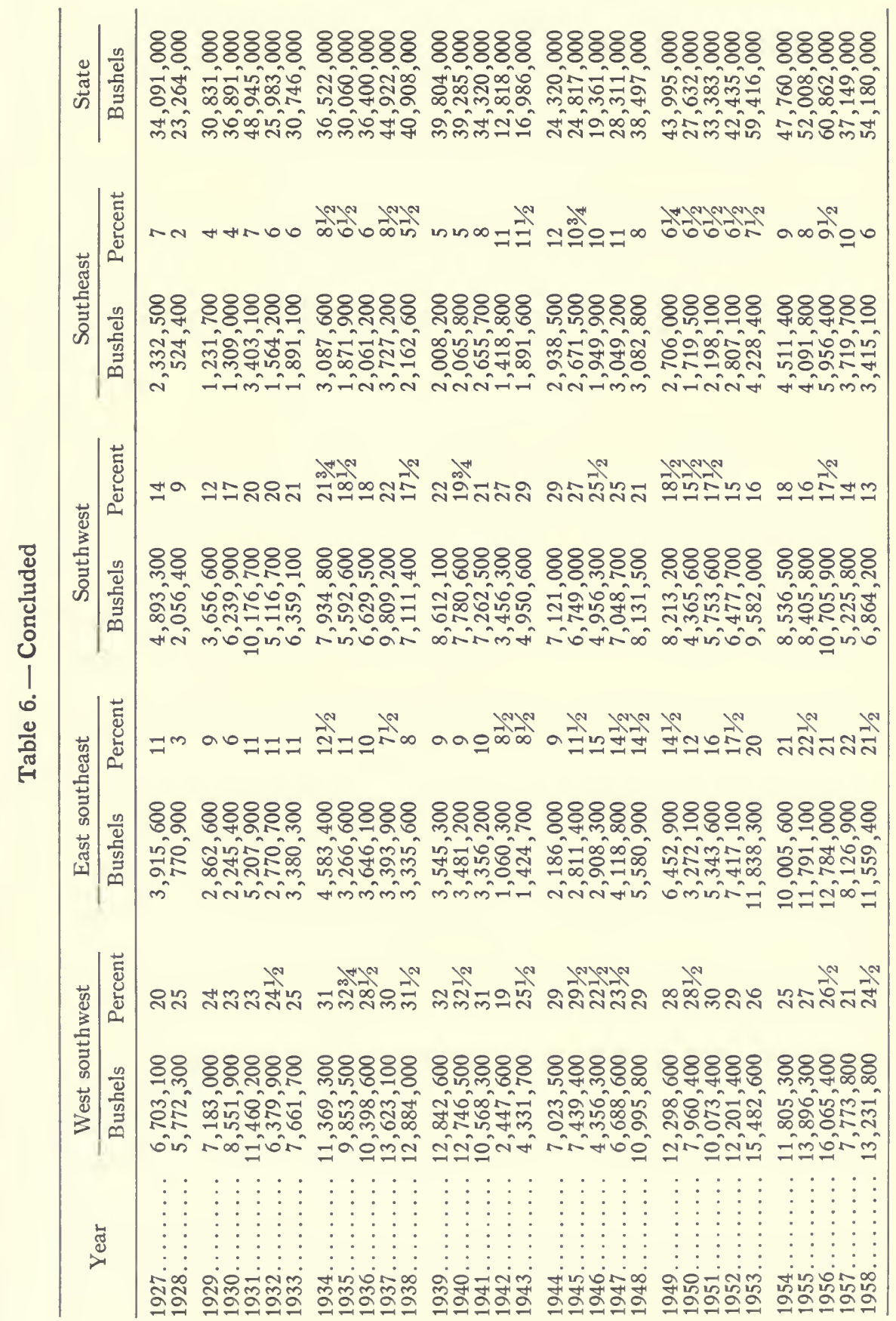




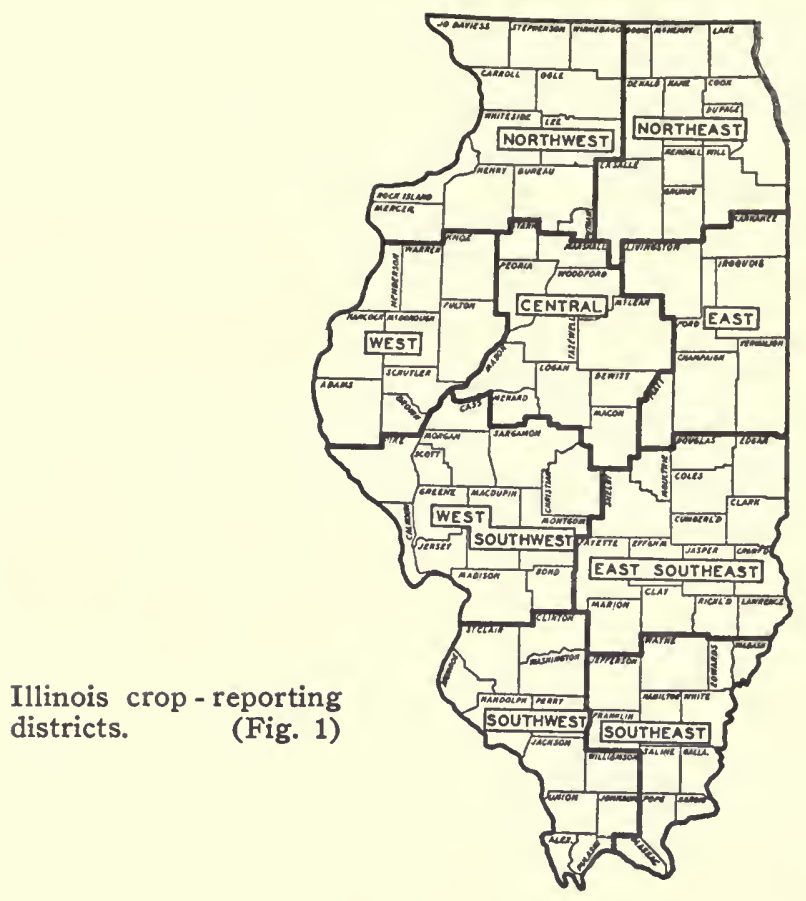

increase is shown. The east southeast district continued to increase its percentage share of total acreage and production. The west southwest district does not show much change from the war period. This district averaged about 25 percent of Illinois' wheat acreage and production in both war and postwar periods.

Land productivity. Crop yields in the years 1957 and 1958 were fairly typical in Illinois. The yields of the nine crop-reporting districts for these two years give a rough index of the productivity of the land (Table 7). The five northern and central districts have the highest overall average yields and the two southern areas the lowest. The west southwest and east southeast districts are intermediate.

The northern and central districts usually have higher average yields for all four crops than the southern areas, but their advantage is relatively less for wheat and soybeans than for corn and oats. Not only do the southern areas have less fertility than the northern and central areas, but they also have less level land and more need to grow wheat in their rotations as a nurse crop for legumes. For these comparative-advantage and farm-management reasons, farmers in the 
Table 7. - Crop Yields, by Districts, Illinois, 1957 and 1958

\begin{tabular}{|c|c|c|c|c|c|c|c|c|}
\hline \multirow{2}{*}{ District } & \multicolumn{2}{|c|}{ Corn } & \multicolumn{2}{|c|}{ Oats } & \multicolumn{2}{|c|}{ Wheat } & \multicolumn{2}{|c|}{ Soybeans } \\
\hline & 1957 & 1958 & 1957 & 1958 & 1957 & 1958 & 1957 & 1958 \\
\hline & \multicolumn{8}{|c|}{ bushels per acre } \\
\hline 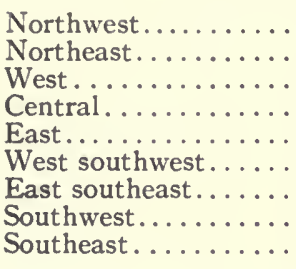 & $\begin{array}{l}75 \\
68 \\
65 \\
72 \\
68 \\
58 \\
49 \\
41 \\
44\end{array}$ & $\begin{array}{l}74 \\
70 \\
76 \\
77 \\
70 \\
72 \\
59 \\
48 \\
47\end{array}$ & $\begin{array}{l}51 \\
47 \\
38 \\
32 \\
26 \\
26 \\
24 \\
23 \\
25\end{array}$ & $\begin{array}{l}59 \\
60 \\
54 \\
\mathbf{5 5} \\
\mathbf{5 4} \\
47 \\
41 \\
29 \\
24\end{array}$ & $\begin{array}{l}28 \\
27 \\
27 \\
25 \\
25 \\
19 \\
20 \\
18 \\
20\end{array}$ & $\begin{array}{l}37 \\
41 \\
34 \\
36 \\
39 \\
35 \\
29 \\
25 \\
21\end{array}$ & $\begin{array}{l}30 \\
29 \\
26 \\
30 \\
29 \\
25 \\
22 \\
20 \\
19\end{array}$ & $\begin{array}{l}28 \\
28 \\
29 \\
30 \\
28 \\
30 \\
25 \\
26 \\
25\end{array}$ \\
\hline State............ & 64.0 & 69.0 & 39.0 & 55.0 & 21.0 & 31.5 & 25.5 & 28.0 \\
\hline
\end{tabular}

southern districts tend to have less flexibility than farmers in the northern and central districts in choice of crop-rotation patterns and proportions.

Relation of production and acreage changes to productivity. The second hypothesis proposed at the beginning of the study stated that any changes in wheat production within Illinois related to changes in price-per-bushel or revenue-per-acre relationships between wheat and other grains should be greater in central Illinois, where there are more alternative uses for resources, than in southern Illinois.

The data on acreage and production changes within Illinois (Tables 5 and 6) support this hypothesis rather conclusively. Changing price and revenue relationships (analyzed on pages 7 to 11 ) were accompanied by considerable increases and decreases in production in the rich central part of the state - the west, central, and east districts and by much smaller changes in the southwest and southeast districts, the poorest section of the state.

\section{Summary}

The purpose of this study was to test two economic hypotheses with respect to wheat production in Illinois: (1) wheat acreage and production decline when prices are unfavorable and increase when prices are favorable compared with competing crops, and (2) wheatproduction adjustments related to price are greater in central Illinois, where there are more good alternatives, than in southern Illinois, where alternatives are more restricted. 
Records on production, acreage, and price of wheat, corn, oats, and soybeans for the 32-year period 1927 through 1958 were analyzed to determine the relation of wheat production and acreage to the priceper-bushel and revenue-per-acre ratios between wheat and the three other crops. Three periods were selected for comparison: prewar (1929-1938), war (1942-1947), and postwar (1952-1957).

Production of wheat decreased 42 percent from the prewar to the war period and increased 136 percent from the war to the postwar period. In the same periods, wheat acreage decreased 41 percent and then increased 48 percent.

From the prewar to the war period, the price of wheat decreased 12 percent relative to corn, 19 percent relative to oats, and 24 percent relative to soybeans. After the war price relationships returned to more nearly the prewar pattern; from the war to the postwar period, the price of wheat increased 11 percent relative to corn, 25 percent relative to oats, and 7 percent relative to soybeans.

Revenue per acre depends on both price and yield. Wheat was at a disadvantage compared with competing crops during the war because both wheat prices and wheat yields increased less from prewar to war than those of other grains. From prewar to war, wheat revenue per acre decreased 38 percent relative to corn, 43 percent relative to oats, and 33 percent relative to soybeans. In the postwar period wheat yields increased rapidly. Coupled with the relative increase in the price of wheat, this resulted in an increase in the revenue per acre of wheat compared with competing crops; from the war to the postwar period wheat revenue per acre increased 50 percent relative to corn, 89 percent relative to oats, and 56 percent relative to soybeans.

Thus the necessary conditions to establish the validity of the first hypothesis are met. The decline in war-period wheat acreage and production was associated with declining price and revenue ratios for wheat compared with competing crops, and the return to approximately prewar price and revenue relationships in the postwar period was associated with greatly increased wheat acreage and production.

Among crop-reporting districts in Illinois, the state's decline in wheat production and acreage from the prewar to the war period was most evident in the rich central part of the state - the west, central, and east districts. In these districts, percentage shares of total wheat production and acreage decreased while in the less productive areas of the state percentage shares increased. From the war to the postwar period, when total production and acreage in the state increased, the percentage of wheat production and acreage in the three central districts either increased or remained constant; in the poorest section of 
the state - the southwest and southeast districts - the percentage shares declined.

Thus the evidence supports the validity of the second hypothesis. Wheat production changes within Illinois related to changing priceper-bushel and revenue-per-acre relationships between wheat and competing grains were greater in central Illinois, where there are more alternative uses for resources, than in southern Illinois.

It is particularly interesting that in spite of the technological changes during the long period studied, the types of changes one would predict on the basis of economic theory dicl in fact occur. The relative changes were in the direction theory indicates they should be.

\section{Conclusions}

The Illinois experience should be roughly representative of wheat production patterns in other eastern corn-belt states and the factors influencing price and production could be expected to be the same. Table 8 gives the winter wheat acreage and production for Michigan, Indiana, Ohio, and Missouri. No detailed analysis was attempted, but inspection shows that all these states had a wartime decline from their 1930's level and that the Indiana and Missouri patterns closely follow that of Illinois (Table 1 ). The patterns of Michigan, which is not truly a corn-belt state, and Ohio differ somewhat from those of Indiana,

Table 8. - Winter Wheat Acreage and Production, Selected States, 1929-1938 Average and 1938-1957 Annually

\begin{tabular}{|c|c|c|c|c|c|c|c|c|}
\hline \multirow{2}{*}{ Year } & \multicolumn{2}{|c|}{ Indiana } & \multicolumn{2}{|c|}{ Michigan } & \multicolumn{2}{|c|}{ Missouri } & \multicolumn{2}{|c|}{ Ohio } \\
\hline & $\begin{array}{l}1,000 \\
\text { acres }\end{array}$ & $\begin{array}{c}1,000 \\
\text { bu. }\end{array}$ & $\begin{array}{l}1,000 \\
\text { acres }\end{array}$ & $\begin{array}{c}1,000 \\
\text { bu. }\end{array}$ & $\begin{array}{l}1,000 \\
\text { acres }\end{array}$ & $\begin{array}{c}1.000 \\
\text { bu. }\end{array}$ & $\begin{array}{l}1,000 \\
\text { acres }\end{array}$ & $\begin{array}{c}1.000 \\
\text { bu. }\end{array}$ \\
\hline 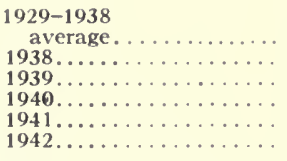 & $\begin{array}{l}1,743 \\
1,803 \\
1,534 \\
1,433 \\
1,476 \\
1,123\end{array}$ & $\begin{array}{l}30,321 \\
28,848 \\
27,612 \\
27,934 \\
34,665 \\
14,052\end{array}$ & $\begin{array}{l}834 \\
913 \\
739 \\
779 \\
741 \\
681\end{array}$ & $\begin{array}{l}16,742 \\
19,519 \\
15,784 \\
18,290 \\
16,286 \\
15,322\end{array}$ & $\begin{array}{r}1,865 \\
2,432 \\
1,845 \\
1,713 \\
1,336 \\
695\end{array}$ & $\begin{array}{r}25,561 \\
31,600 \\
30,424 \\
32,547 \\
18,036 \\
9,035\end{array}$ & $\begin{array}{l}2,004 \\
2,381 \\
1,906 \\
1,959 \\
1,959 \\
1,724\end{array}$ & $\begin{array}{l}40,211 \\
46,420 \\
37,150 \\
42,121 \\
48,978 \\
36,205\end{array}$ \\
\hline $\begin{array}{l}1943 \ldots \ldots \ldots \ldots \ldots \ldots \ldots \ldots \\
1944 \ldots \ldots \ldots \ldots \ldots \ldots \ldots \\
1945 \ldots \ldots \ldots \ldots \ldots \\
1946 \ldots \ldots \ldots \ldots \ldots \ldots \\
1947 \ldots \ldots \ldots \ldots \ldots \ldots \\
1948 \ldots \ldots \ldots \ldots \ldots\end{array}$ & $\begin{array}{l}955 \\
1,325 \\
1,555 \\
1,366 \\
1,571 \\
1,775\end{array}$ & $\begin{array}{l}15,274 \\
26,488 \\
34,980 \\
29,369 \\
36,133 \\
38,162\end{array}$ & $\begin{array}{r}660 \\
987 \\
982 \\
864 \\
1,192 \\
1,395\end{array}$ & $\begin{array}{l}11,196 \\
23,670 \\
27,005 \\
22,896 \\
29,800 \\
36,270\end{array}$ & $\begin{array}{r}973 \\
1,294 \\
1,304 \\
1,213 \\
1,321 \\
1,785\end{array}$ & $\begin{array}{l}12,649 \\
21,998 \\
18,256 \\
18,195 \\
24,438 \\
39,270\end{array}$ & $\begin{array}{l}1,603 \\
2,035 \\
2,129 \\
1,831 \\
2,170 \\
2,353\end{array}$ & $\begin{array}{l}26,449 \\
46,805 \\
57,483 \\
48,522 \\
49,028 \\
57,648\end{array}$ \\
\hline $\begin{array}{l}1949 \ldots \ldots \ldots \ldots \ldots \\
1950 \ldots \ldots \ldots \ldots \ldots \\
1951 \ldots \ldots \ldots \ldots \ldots \\
1952 \ldots \ldots \ldots \ldots \ldots \\
1953 \ldots \ldots \ldots \ldots \ldots \ldots \ldots \ldots\end{array}$ & $\begin{array}{l}1,740 \\
1,533 \\
1,426 \\
1,540 \\
1,648\end{array}$ & $\begin{array}{l}39,150 \\
32,193 \\
23,529 \\
36,960 \\
46,144\end{array}$ & $\begin{array}{l}1,297 \\
1,141 \\
1,232 \\
1,429 \\
1,515\end{array}$ & $\begin{array}{l}35,019 \\
29,666 \\
30,800 \\
36,440 \\
44,692\end{array}$ & $\begin{array}{l}1,946 \\
1,359 \\
1,318 \\
1,252 \\
1,578\end{array}$ & $\begin{array}{l}35,028 \\
23,782 \\
22,406 \\
27,544 \\
41,028\end{array}$ & $\begin{array}{l}2,353 \\
2,118 \\
1,906 \\
2,249 \\
2,384\end{array}$ & $\begin{array}{l}60,002 \\
46,596 \\
34,308 \\
55,100 \\
69,136\end{array}$ \\
\hline $\begin{array}{l}1954 \ldots \ldots \ldots \ldots \ldots \ldots \ldots \ldots \\
1955 \ldots \ldots \ldots \ldots \ldots \ldots \ldots \\
1956 \ldots \ldots \ldots \ldots \ldots \ldots \ldots \\
1957 \ldots \ldots \ldots \ldots \ldots \ldots\end{array}$ & $\begin{array}{l}1,318 \\
1,186 \\
1,186 \\
1,281\end{array}$ & $\begin{array}{l}40,199 \\
34,394 \\
36,173 \\
32,666\end{array}$ & $\begin{array}{r}948 \\
948 \\
1,043 \\
991\end{array}$ & $\begin{array}{l}29,870 \\
27,966 \\
31,290 \\
28,739\end{array}$ & $\begin{array}{l}1,373 \\
1,551 \\
1,660 \\
1,643\end{array}$ & $\begin{array}{l}41,190 \\
48,081 \\
50,630 \\
37,789\end{array}$ & $\begin{array}{l}1,740 \\
1,496 \\
1,526 \\
1,495\end{array}$ & $\begin{array}{l}46,980 \\
43,384 \\
39,676 \\
32,890\end{array}$ \\
\hline
\end{tabular}

a Source: Agricultural Statistics, U.S. Department of Agriculture. 
Illinois, and Missouri, and a detailed analysis beyond the scope of this study would be necessary to determine the reasons.

Wheat production in the eastern corn belt appears to be closely related to changes in wheat price and revenue relationships to competing crops. Although a period in which both price and technological changes combine to reduce wheat production may not occur again, lower wheat price supports relative to those of corn, oats, and soybeans, or an increase in demand (and hence, price) for competing crops relative to wheat could be expected to reduce the incentive to produce wheat and to reduce wheat acreage and production in the region.

The results of this study indicate that lower wheat price supports and abolition of acreage controls would cause a shift of wheat production from the eastern corn belt to other regions of the country. This shift would at least partially compensate wheat producers in other regions for the loss of income due to lower wheat prices.

The land shifted from wheat in Illinois and other eastern corn-belt states would go into feed grains. However, the net addition to the feed grain supply would be something less than the total production from these shifted eastern corn-belt acres because land in other regions of the country better adapted to wheat than feed grains would be shifted from sorghum, barley, and oats to wheat. 



$$
\text { . }
$$
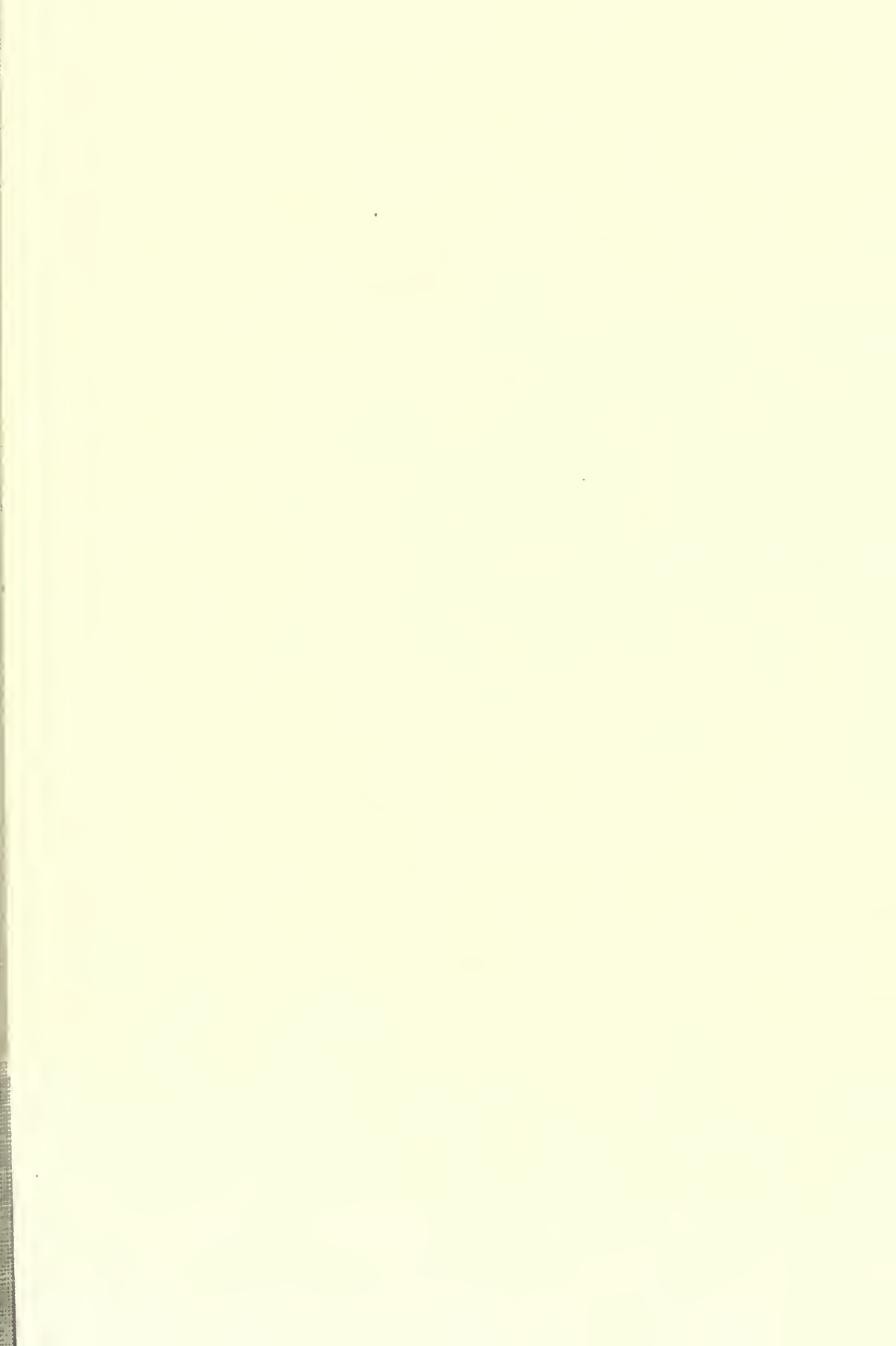
UNIVERSITY OF ILLINOIS-URBANA |||||||||||||||||||||||||||||| |||||||||||||||| 